\title{
The constructivist challenge to the debate on East Asian security in the new century
}

\author{
Chen Dongxiao
}

How should we perceive and anticipate the prospects for East Asian security-both Northeast and Southeast Asia-in the 21st century? Is this region prepared for a new millennium of peace and stability, or will it be one of the main sources of future chaos and global conflict? Western scholars have been and are still offering their observations and insights on these issues. In general, the theoretical foundation for such analyses are neo-realism and neo-liberalism, two major schools of contemporary western international relations (IR) theory. By combined analyses at structural and unit levels, they have tried to draw a picture of the region's security prospects mainly through three prisms- the 'power-structure' perspective, the 'domestic regime' perspective and the 'international institutional' perspective. Most analysts have expressed rather pessimistic views about the future of East Asian security (Brown et a1. 1996; Ross et al. 1995; Alagapa 1998; Swaine and Tellis 2000; The Asia Foundation 2001).

Despite their perspicacity and wisdom, some common limitations exist in these mainstream schools of thought. When western scholars try to apply these theories and analytical tools to the study of East Asian security, they tend to neglect regional actors' (states) uniqueness in their 'identity-learning practice' process. For instance, both neo-realism and neo-liberalism tend to define pation-states in the international arena as 'a rational strategic man' with a predestined and unitary national interest. When applied to the study of state behaviour, this underlying assumption often underestimates the diversity of identity formation, preferences, and interests of individual nations.

Meanwhile, constructivism, a newly established school of IR theory, has pinpointed the inherent limitations of conventional analytical frameworks. In constructivist explanations, each nation has its particular identity, which indicates 
and implies a distinct understanding of the 'ego's' (that is, the state's) preferences, motivation, interests, and behaviour as well as the consequences thereof. 'A state understands others according to the identity it attributes to them, while simultaneously reproducing its own identity through daily social practice' (Hopf 1998, 173). Therefore, the uniqueness of each nation's identity-learning-practice process directly and profoundly influences its own perspective of national security and practice, and as a result, determines its international security practices.

International relations theory often reflects evolving trends in world order and thus provides a good roadmap for understanding global security issues. East Asia is no exception. In the sections that follow, I will outline four major theoretical perspectives on East Asian security. The first section of this chapter outlines some of the essential elements of constructivism with a focus on the identity-learning practice process. The second to fourth sections consider the three mainstream analytical frameworks for studying East Asian security respectively versus the challenges and contributions of constructivism in this field. The last part tries to address some of the promises and problems regarding regional security multilateralism and its development in East Asia from a constructivist perspective.

\section{Identity-learning-practice process: some major elements}

Constructivism is usually regarded as a challenge to the continuing dominance of neo-realism and neo-liberal institutionalism in the study of international relations in the west, particularly in the United States (Onuf 1989; Katzenstein 1996; Lapid and Kratochwil 1996; Wendt 1999). Constructivism offers an alternative understanding of a number of the central themes in IR theory where the difference of each paradigm has its origin in epistemology, methodology and ontology (Burchill and Linklater 1995, 197-99; Wendt 1999, 33-40). Three elements make constructivism a distinct school of IR theory building.

First, constructivists argue that the identity (self-perception) of one state is the main source of interest formulation of that particular nation. Interests are the products of identity and intersubjective identities that are sufficiently stable to ensure predictable patterns of behaviour are the prerequisite for durable expectations between states (Hopf 1998, 174-5). In contrast to the mainstream paradigms (either neo-realism or neo-liberalism) which usually define a state's interest as given and constant, constructivists maintain that states do not a priori know exactly what their interests are and how to realize them. One of the most distinctive features is that constructivists challenge the 'rationalist' assumption (underlying neo-realism and neo-liberalism) of a state's interest as exogenouslygiven, and refuse (or hesitate) to regard states, or power actors as a 'rational strategic man'. For rationalists, state preferences are unproblematic-they are 'exogenously' formed and are based on a power-maximizing rationality (Hobson $2000,145-6)$. Constructivists also hold that states' identities and preferences are much more malleable than allowed by the mainstream rationalism theory. In the constant interstate interaction and learning, states' identities and preferences are 
capable of being molded and re-molded by norms through subtle and discursive processes of socialization (interaction with other states). Two cases are noteworthy here, one is Gorbachev's new thinking and reform in mid-1980s, the other is China's changing identity from an inward-looking 'Middle Kingdom' to a more open-minded, responsible state that is willing to integrate into the international community.

Second, constructivists stress the 'mutual constitution' between the ideational structures and agents (states). On the one hand, it is the social normative structures that constitute states' interests and identities. For example, Wendt claims that international social relations range from a Hobbesian condition of a war of all against all, to a Lockean culture of restraint and finally, to a Kantian culture of friendship (Wendt 1999, 246-308). But on the other hand, structures per se are the products of discursive social practices of actors. Anarchy, as constructivists assert, is only one of the international structures. Anarchy is an empty vessel and has no intrinsic logic of its own unless some inter-subjective set of norms and practices are filled in (Wendt 1999, 249). International structures exist only through the reciprocal interaction of actors employing constitutive rules and social practices.

Third, constructivists insist that there is no overarching determinant of one state's identity and practice in world politics. A state's identity constitution and practice can be better understood in multiple dimensions, including this state's historical evolution, cultural development, political and social institutions, as well as its economic situation. Constructivists are particularly well known for their emphasis on culture (both domestic and international) as a constitutive effect on identity and interest.

Thus, constructivism's emphasis on the socialization of international relations, interaction and the identity-learning-practice process of individual states has some important theoretical implications for international studies. Constructivists explain the nature of international relations mainly in terms of the interaction of states' identities. As they see it, the causes of conflicts and war grow partly out of the conflicting identities of states. Constructivists see 'international cooperation not in the minimalist game theoretic terms, nor as the byproduct of purely utilitymaximizing behaviour by states, but as a process of social learning in which interactions produce shared understanding of reality, redefined interests and may lead to the development of collective identities to ameliorate the security dilemma' (Acharya 1999b). Finally, by positive interaction among states, socialization in international relations can gradually develop the norms of peaceful conduct of conflict resolution and ingrain them into states' security behaviour. All these points are productive in complementing and contributing to the conventional ways of thinking about East Asian security.

\section{Structure of anarchy: balance of power or balance of threat?}

A 'power-structure' perspective is one of the hallmarks of neo-realism's paradigm (Waltz 1979; Gilpin 1981). When applied to the analysis of East Asia security, this 
school tends to hold that the burgeoning regional power (referring mainly to China) poses a long-term danger to Asia-Pacific security. As a rising power's comprehensive strengths aggregate and expand, so do its national interests and aspiration for international status. According to those pundits of realism, as states grow wealthier and more powerful, they not only seek greater world-wide political influence (control over territory, the behaviour of other states, and the world economy) commensurate with their new capabilities; they are also more capable of expanding their interests and, if necessary, of waging large-scale, hegemonic wars to revise drastically or overthrow entirely the established order. Some western scholars predict that a future Chinese hegemony in East Asia is a strong possibility because of its proclivity to use force because of domestic institutional flaws and external pressure (Roy 1996). Realists stress the dangers of rising power (Gilpin 1981).

Following the lines of 'established power versus rising power' pattern, realists argue that under the current power configuration in East Asia, the driving forces behind the re-strengthening military coalitions between the United States and its allies in East Asia and the looming prospect of regional arms races are all motivated by these states' desire to form a balance against the rising power, say of China (Frieberg 1996). With the 'power-structure' perspective, some scholars predict with pessimism that Asia is likely to see more international conflict than Europe, and in the long run it is Asia that seems far more likely to be the cockpit of great power conflict because Asia is evolving into a multipolar and more fragile structure in realist terms, without the mitigating factors that contribute to stability in post-Cold War Europe, such as stable democratic states, a lesser degree of interdependence, and less proclivity to war.

As constructivists have pointed out, there are two main problems with neorealism. One lies in its tendency to prefix the interests of states as given and uniform. The other is its uni-dimensional understanding of the interaction between 'agent' and 'structure'. From a constructivist perspective, problematic neo-realist predictions and conclusions about East Asian security are manifested in several ways.

First, it is too simplistic to rush to the conclusion that a rising China, like her 'predecessors' in history (Germany before the First World War and Germany and Japan before the Second World War), will inexorably adopt an aggressive strategy to challenge the established power and to reconfigure the existing international system.

The historical record has demonstrated that the cause of war between rising and extant dominant powers is much more complex than the neo-realists have explained. There is nothing foreordained about such a war. Some of them were mainly the result of misperception and the failure of statesmanship, as even the arch-realpolitik practitioner, Henry Kissinger, has argued (Kissinger 2001, 136-7). Some of them were directly linked with prevailing national ideology and strategy, such as the dominance of ultra-nationalism and ethnocentrism in Nazi Germany, 
For Japan in the 1930s, the driving force for war was also an expansionist perception of altering Japan's overwhelming dependence on overseas natural resources. It is changes in national interests and perceptions of how to achieve them that makes war likely (Van Evara 1999),

Whether China as a rising power will take a cooperative or assertive strategy vis-à-vis the existing international system has been a controversial issue since the mid-1990s. However, the bulk of the arguments, whether in support of a 'more cooperative China' or of a 'more assertive China', have been grounded in what Wendt calls 'materialist and rational ways of thinking'. Few have investigated the origin of China's national interest, preferences, and practices; even fewer have treated the idea of identity as dynamic and evolutionary. For instance, some realists attributed China's turn to assertiveness in the future to 'its historical memory of past greatness and the desire to restore previous eminence; its determination to erase the painful legacy of a century of national humiliation; its desire to recreate the traditional Sinocentric world order as a means of regulating the political and economic structures of super- and subordination; its belief that China's external security in past was primarily assured by a strong state able to dominate or at the very least neutralize the strategic periphery; and so on' (Swaine and Tellis 2000, 189).

As Wendt $(1999,324-36)$ has eloquently explained, national interests and practices, fundamentally speaking, stem from national identity that itself is formed through cultural selection, an evolutionary and dynamic mechanism which includes imitation and social learning. This important idea questions the static treatment of identity. While recognizing these deep-rooted elements and their effect on China's strategic culture and the formation of its national identity, constructivists also stress the significance of identity change through imitation and social learning, arguing that institutions can socialize China, and 'teach' China new interests through a complex set of ideational channels including NGOs, transnational coalitions, and domestic constituency-building (Johnston and Ross 1999; Economy and Oksenberg 1999). For instance, some scholars examining China's performance in international institutions believe that the quality of China's participation in such institutions has steadily improved in the past few years. A number of instances of China's involvement in security institutions are related to its self-image and reputation which in turn is associated with the transformation of the country's identity (Johnston 1999).

Second, a turn toward confrontation and even war is not an inevitable outcome in the relationship between a rising great power (China) and an extant dominant power (the United States). The central questions of whether the emergence of a new great power will be destabilizing - and the likelihood that established powers can and will peacefully co-exist with this rising power within the existing order-can only be answered by looking at the outcomes as the products of combined effects within the structures of the international system. For instance, the concurrent uni/multipolar world system indicates a much more complicated post- 
Cold War structure for the rise of China than 'fatalists' have predicted (Huntington 1999; Calleo 1999; Kupchan 1999). Generally speaking, a multipolar structure is more conducive to the emergence of a new great power partly because the power requirements for a polar system in a multipolar system are less demanding than tri, bi, or uni-polar world structures. Thus, in international politics parlance, the emergence of China as a great power represents 'a change within the structure of the system (multipolar system)' more than 'a change of system structure as from unipolar into a bipolar one, or from a bipolar system into a tripolar one' (Schweller 1999,6 ). Even by the logic of neo-realists, the complex system of world structure per se is at least one of the mitigating factors for future relations between China and America.

Moreover, there is a decisive force behind the interaction between dominant power(s) and rising power(s). In the case of Sino-US relations, the behaviour and attitudes of America towards China usually shape the features of their bilateral relations. The United States has choices somewhat similar to those faced by the British at the end of the nineteenth century. It can oppose China (and other rivals) by pressing for a seamless 'global' system that remains under its own hegemony. Or it can try to accommodate by coaxing others into a global sharing of power, with some mix of regional spheres of interest and collective world responsibilities. It is fair to say that the United States has gained some due credit as a 'benign power' rather than a predatory hegemon in maintaining status quo stability after the Cold War. However, America's exceptionalist and hegemonic instincts are not abating in the new century. America's political imagination has not really adjusted to an unfolding multipolar system. As some analysts have asserted, the real danger lies in the gap between American unipolar imagination and the pluralist trends in the real world, rather than in the gap of the redistribution of material power and the extant system itself, as neo-realists have identified (Calleo 1999, 11-12). This danger manifests itself in a series of policies that increasingly position the United States in opposition to the interests of not only China but also those of Russia and even Europe.

As a rising power, China's interaction with the existing system and dominant power(s) in particular is exerting both causal and constitutive effects on its preferences and reactions vis-à-vis the dominant power(s). The effect can be positive and negative, as constructivists have convincingly explained. Hence, the likelihood of peaceful competition and coexistence between rising and dominant powers will depend on each one's identity and how each side perceives and knows the other. This was the case with British appeasement of the United States at the turn of the nineteenth century, where the British recognized that the latter was motivated primarily by insecurity and the need for reassurance, and that its nonsecurity aims were quite limited (Rock 2000, 25-49; Coicaud 1999). If the dominant power regards any emerging power as an enemy and adopts a policy of containment, it will become a self-fulfilling prophecy because the rising power in return is forced to take on an assertive strategy. It is the behaviour and strategy of 
the dominant power that fundamentally shape the preferences and national interests of the relatively weaker one.

Third, the various security practices of East Asian states towards big power(s) lie in each state's particular perception of the regional security environment, including the source of threat; they are neither merely determined by the anarchy structure nor motivated to balance against any rising power. Following the lines of neo-realist theory, states stationed around China should have either adopted a 'balancing/containment' strategy against China in alliance with the dominant powers, or 'bandwagoned' with China. However, the emergence of China has actually led to a convergence in engagement policies across most East Asian states with a common theme of 'hedging' on the one hand, and varying degrees of engagement on the other. There are a number of factors working to influence and shape the different policies. Some of them can be subsumed in the realpolitik category, such as material power differentials and alliance opportunities. Others are in the non-realpolitik camp, including trans-governmental penetration and crossnational coalitions, degree of economic independence, identity and historical memory as well as interest perception. Nevertheless, the different perceptions of a common threat have played the most significant role in policies toward China (Johnston and Ross 1999, 280). This has explicitly showed that there is no overarching 'balance of power' logic for their strategies.

As Amitav Acharya (2000) explains, there is no consensus on external threats among East Asian states. For Southeast Asia at present, there is a shared concern over the growth of Chinese power, but no common perception of a Chinese threat; for Northeast Asian states, there is serious to moderate divergence on external threat perceptions, but a shared concern about the prospect of US-China rivalry. Again, it seems to substantiate one of the arguments often held by constructivists, that a 'balancing strategy' is not adopted by one state to 'balance' material power; rather, it reflects the state's cognition and perception of an 'external threat'. Material power growth per se does not equal a threat.

\section{Domestic regime perspective: democratic peace or normative peace?}

The 'domestic regime perspective' is both an old and new approach in IR theoretical frameworks to explain the interaction between domestic political institutions and foreign strategy and practice. Traditionally, liberal transnationalists often claim that democracies are inherently more peaceful than other 'inherently flawed' regimes, such as authoritarian ones. This position is severely undermined by the fact that there is little evidence to support claims for the superior inherent peacefulness of any particular form of societal, economic or government organization. However, in the past decade, the literature on democracy and foreign policy, especially 'democratic peace', is expanding rapidly (Russett 1993; de Mesquita, Jackman, and Siverson 1991; Journal of Peace Research 1992; Chan 1993). It contends that although democratic regimes are nearly as violence- 
prone in their relations with authoritarian states as authoritarian states are towards each other, they are more peaceful between and among democratic states because such regimes posses cultural and institutional constraints against going to war with each other (Russett and Starr 1996, chs 8 and 14).

When analysing East Asian security affairs through the 'democratic peace' lens, scholars usually express a less optimistic view. First, as they explain, progress towards a norm of liberal democracy, prosperity, socio-economic equity, and postnational political culture is still at a very early stage. In East Asia there will continue to be interaction between democratic and non-democratic states. With such a diversity of regimes in East Asia, this school contends, if non-democracies are hawkish and anticipate that democratic countries (doves) will be slow to go to war, they may be more likely to threaten or bully a democracy to make concessions. That in turn would raise the threshold of 'provocation' facing the democracy and perhaps overcome its initial unwillingness to fight. The second approach is 'democratic transition theory', which focuses on states making the shift from authoritarianism to democracy. It suggests that competitors for leadership in these regimes adopt aggressive foreign policies that garner popular support by tapping into nationalist sentiments and elite support by placating the institutional remnants of authoritarian rule, especially the military. There is increasing concern among western scholars about the growth of nationalism among the Chinese people in the 1990s and its impact on China's foreign policy (Whiting 1995; Wang 1997; Swaine and Tellis 2000).

On the one hand, constructivists agree with parts of the "democratic peace" thesis, particularly those concerning norms and culture. Two leading 'democratic peace' advocates themselves have concluded, by comparative and critical tests of the explanatory capacity of the role of cultural/normative or institutional/structural factors in preventing joint democratic conflict, that shared political and cultural norms form the hub around which democratic peace revolves (Moaz and Russett 1993, 624-8). The norm/culture approach actually consists of two strands. One emphasizes the quality of liberal democratic norms and culture. In short, elements such as perception of individual rights, expectation of limited government, and toleration of dissent by a presumably loyal opposition are conducive to the political culture of peaceful resolution of conflicts within a state boundary. Second, following the first explanation, the culture, perceptions, and practices of peaceful resolution without the threat of violence apply across national boundaries toward other democratic countries. Without such shared norms/culture for peaceful relations between democracies, peace is unpredictable. This emphasis on the shared meaning of norms/culture in determining peace comes very close to the constructivist emphasis on intersubjective understanding and expectations and the social knowledge embedded in international institutions (Wendt 1994, 385).

From the constructivist perspective, however, the democratic peace literature is still too narrow in identifying and defining cultural norms and their causal effect on peace. It has by definition coupled the absence of war to a particular type of state. 
For instance, different periods of the history of both Africa and Latin America have been marked by long stretches of little or no warfare between states. These pacific periods are obviously not associated with any 'objective' indicators of democracy. How to understand these neglected zones of 'authoritarian peace' (Hopf 1998, 192)? Why does common culture, more broadly conceived, also have or not have a dampening impact on international conflict, if shared political culture makes cooperation more likely? (Henderson 1998) Does the concept of security of community have stronger explanatory power in offering the possible relationship between the growth of community and pacific relations, and making a more exacting and demanding explanation of a stable peace? For instance, the fact that the members of ASEAN in Southeast Asia have managed to settle their disputes without resorting to violence for the last three decades seems to verify the idea of a security community in a non-democratic context. As Acharya argues, liberal democracy is not a necessary condition for a security community. Moreover, there is a growing ASEAN identity that represents a potential source of collective identity (Acharya 1998).

The constructivists' approach aims at apprehending how the social practices and norms of states construct their identities and interests. They argue that certain processes can lead states to positively identify with one another. Such positive collective identification holds the key to understanding why liberal democracies rarely fight one another (Kahl 1998/99). Put simply, is it about the quality of ideas themselves -.-rather than the mere fact that they are shared - that leads people who reside in different territorial spaces to feel secure from organized violence in a liberal security community? What lies behind the stable peace seems to have less to do with the specific regime than with the shared norms between and among the states with regard to external threat, the use of force and the resolution of conflicts. Thus constructivists propose a research agenda which inquires into whether there exists such 'shared meanings and understandings' in East Asia, which promote collective identity, mutual trust, and peaceful change.

\section{Institutional perspective: interest-based behaviour, but which and how?}

The 'International Institutional Perspective' (also called neo-liberal institutionalism) is generally regarded as the product of neo-liberalism, combined with some elements of neo-realism. It is one of the main schools of IR theory to illuminate international cooperation. This perspective stresses the formal and informal institutions formed between and among states to push forward cooperation and further their mutual interest for survival (Krasner 1983; Ruggie 1983; Keohane 1998). It expresses pessimism about East Asia's security cooperation because of the lack of conditions for successful institutionalization that have contributed to its effectiveness in post-Second World War Europe, such as the weakness of regional security mechanisms, a short history of international security cooperation, salient conflicting rather than common security interests, diverse 
cultures and the lack of a transnational sense of community (Frieberg 1996). Ever since the 1997 financial crisis in East Asia, suspicion of the future development of security cooperation and multilateralism has been escalating. The suspicion particularly involves the weak leadership of multilateralism because ASEAN is too preoccupied with its own internal troubles (Acharya 1999a).

While sharing these concerns with the institutionalism perspective, constructivists challenge the perception of cooperation on the basis of pre-given interests and binding contracts between and among states. For constructivists, national interests involve both 'instrumental values' (such as economic and security interests) and 'non-instrumental values'. The latter camp refers to national dignity and ethnic historical sentiments which are related to one's identity and are much more complex, elusive and distinct between different states (Kimura and Welch 1998, 231-2). Constructivists see cooperation not in terms of minimalist game theory, or as the byproduct of purely utility-maximizing behaviour by states.

In East Asia, three cases are noteworthy here for a further understanding of constructivist perspectives. The first one is Japan's claim for the Northern Territory in its relations with Russia. From a constructivist perspective, the key question to cooperation is not whether material interests between states exist or do not exist. The key question is how states understand or interpret their interests within a particular issue. Otherwise, it would be difficult to understand why Japan persists in seeing the reclamation of its Northern Islands from Russia as a prerequisite to further development of its ties with Russia, because those Northern Territories' instrumental values (economic and security values) are very limited. Japan's strong desire to recover those islands is not a response to the game theory process. Japan is not maximizing anything material in seeking the return of the Northern Territory, according to some analysts' explanations. Instead, the answer lies in the Japanese sense of national identity that includes the Northern Territory through a long period of socialization. Japanese believe that 'Japan will not be complete, Japanese will not feel themselves fully to be masters of their own homeland, until the foreign occupation of these islands ends, or until Japanese cease to think the islands are an intrinsic part of Japan' (Kimura and Welch 1998, 217-23). Until then, the issue will remain at the top of the Japanese foreign policy agenda. Similar conditions also help explain Russia's reluctance to return the islands. Thus, the disputes over the Northern Territory between two countries transcend realpolitik geostrategy and reflect the historic hostility and identities of the two states.

The second case is China's involvement in international and regional security institutions. As noted before, neo-liberal institutionalists' focus on how selfinterested actors construct institutions to enhance cooperation prevents them from considering fully how interstate and transnational interaction can alter or socialize states' identities and interests. The institutionalist approach can only depict the adjustment of China's behaviour to the anticipated preference of others within international security institutions. Thus they tend to regard China's increasingly active engagement with security institutions as at best tactical, mainly 'coerced by 
institutions' monitoring and sanctioning provision' (Whiting 1997). Constructivists, however, try to investigate further the impact of institutions on China's policy, and to figure out the underlying reasons for China's policy adjustment. As Johnston and Evan observed, China's cooperation with security institutions is multi-dimensional. More cases in China's cooperation are related to image or reputation, which is also related to China's transformation of identity. As they explained, China's self-identification has been undergoing a change and a blurring. China is caught in the 'tension in diplomacy between China's determination to show itself as an active involved participant in international institutions (new responsible power identity) and the desire to minimize commitments and constraints required by participation (traditional sovereigntycentric, major power identity) (Johnston and Ross 1999, 248-54). Although still tentative and controversial, the studies on China's involvement with the identitylearning-practice approach have indicated that the "material and relative power maximizing' explanation fits poorly here. It is evident that China nowadays is much more sensitive to the normative constraints and image generated by participating in international security institutions than ten years ago. China is experiencing a kind of socialization under the international context of security institutions. While we are not yet certain that multilateralism or even otherregarding cooperative security principles have been socialized in China's decisionmakers, at least we feel certain of their effects on China's behaviour and policy.

The third case in question is security cooperation among ASEAN members, as analyzed by Acharya (1998). Southeast Asia was once described by an American observer as 'a region without any feeling for community, without much sense of shared values and with few common institutions'. Yet it is also the first area in the Asia-Pacific region to work towards a security community, even without those immutable and predestined variables (which are stressed by rationalist and neorealist/neo-liberal institutionalists as a prerequisite). According to one analyst's observation, ASEAN's inception and early advancement was influenced and promoted by some common security perceptions and economic cooperation. But it is also noteworthy that there was a lack of common perception of external threat among ASEAN members, and that intra-ASEAN trade volume was far less than the inter-regional trade transactions. Moreover, neither security nor economic issues were sufficient for the construction of ASEAN. Through various steps and stages, ASEAN members have deliberately created a set of norms, symbols and habits of regional existence to promote the ASEAN regionalism and collective identity. Four elements have been crucial for the process of collective identity formation: multilateralism; norms and symbols of the 'ASEAN-Way' of consensus seeking/building; informal decision-making procedures; and a shared quest for regional autonomy. ASEAN's experience again challenges the rationalist and materialist foundation of cooperation assumed by institutionalists. It is better explained by constructivists who emphasize the process of social learning in which interaction produces shared understandings of reality, redefines interests and may 
even lead to the development of collective identities that could ameliorate the security dilemma.

\section{Constructivism's challenge and promise: can the concept of a security community thrive in East Asia?}

Since the end of the Cold War, the development of East Asian security has been quite complex and multidimensional. There is no overarching security architecture at present. In the near or mid-term future, East Asia is still unlikely to develop a single model of regional security structure. Security mechanisms will remain diverse, with mainly three strands of mega-trends. One is multilateralism, though it is still at an early stage. The second is the balance of power, partly manifested in the form of re-strengthening the regional alliance systems. The third strand is dynamic bilateral interaction, which has become increasingly pronounced in the past few years (Baker and Morrison 2000, 9-18; Xinbo 1999, 81-3).

As some analysts have observed, these trends co-exist and mutually interact. For instance, the intense bilateralism of recent times indicates not only the lack of a sustainable security architecture, but also enormous uncertainty confronting this region, regarding both the development of multilateral security arrangements and the alliance system (Naidu 2000).

However, the future and promise of East Asian security in the 21st century does not depend on alliances and the balance of power, which are mainly built on the neo-realist and power-structure perspectives, and dependent upon static and cyclic interpretations of international politics. Instead, multilateral endeavours, despite their preliminary nature and frustrations, will stand as a challenge to the extant regional security situation and promises future stability and a security community in East Asia.

Multilateral security architecture (or multilateralism) is one indicator of a mature security community. According to Emanual Adler and Michael Barnett $(1998,55)$, multilateralism involves a higher degree of consensus in decision making, conflict resolution and conflict adjustment among community members than other types of interstate relations. This system also reflects a high degree of trust that common interests will be handled through consensual mechanisms that automatically incorporate the interests of all members.

When keeping this ideal conceptual framework in mind, we find that the concurrent East Asian regional multilateral endeavours are still at a very nascent phase of a truly established and mature multilateralism. It is therefore even further away from becoming a security community. Whether it can serve to precipitate mutual trust and the collective identity of a security community will be determined by an array of factors. These involve regional strategic attitudes regarding the threat and use of force, the pace of regional political and economic integration, the interaction among members and their willingness (especially the regional big powers) to embrace the concept of multilateralism, and finally, the concerted effort 
by regional members to create a sense of collective identity (Acharya 2000; Xinbo $1999,81)$. In particular, East Asian multilateral endeavours will have to live with the reality and challenge of its regional security condition, and intensify efforts to remove some inherent obstacles to the positive interaction of states.

The first positive element in the East Asian security prospect is a general negative cultural attitude towards war as a mean of conflict resolution. War has not served Asia well in the minds of its people. The history of war in East Asian countries is not preserved as glorification but suffering. The memory of war, in general, is not to reinforce the image of a warrior-state, but to stress the value of peace and peacemaking (Berry 2001). Moreover, some of the common themes in East Asian strategic cultures, such as a long-term view of policy-making and conflict resolution, the equality of cultures, consensus building and informal incrementalism, all contribute to peace and a conflict-averse culture (Trood and Booth 1999, 339-41).

Second, the extant regional and sub-regional security instruments can still work as a norm-triggering platform to buttress a future multilateral mechanism. Existing bodies, such as ARF and its matrix, ASEAN, because of their ample experience in peaceful resolution in multilateral processes both among the member states and with outside powers, have been established for constructive dialogue and nonviolent norms and cultures. ARF's prominent traits such as 'cooperative security', its emphasis on 'inclusiveness' and a 'gradualist approach' are all conducive to an atmosphere of creating norms of peaceful rather than military resolutions of disputes. So is ARF's objective of fostering the habits and mechanisms of constructive dialogue and consultation on political and security issues, even if this 'ARF way' has been questioned and discounted as less effective (Acharya 1998).

Third, the big powers' participation and their capacity to diffuse the norms of peaceful resolution, constructive dialogue and mutual confidence and trust are indispensable elements for the survival and effective operation of the multilateral security institution.

Because ARF was initially established as a partial response to territorial disputes (South China Sea) with China and concern about US military readjustment in East Asia after the Cold War (Antolik 1994, 125), it would be unthinkable without the commitment of the big powers concerned. This problem has been exacerbated after the Asian financial crisis because ASEAN members are preoccupied by domestic problems, and their leadership of regional security institutions (such as ARF) has been seriously questioned. Fortunately, the past few years have seen an increasing interest and willingness by big powers to embrace multilateralism, including engagement with ARF, though at a different level of participation, and to address security concerns and disputes through this forum.

China's engagement with regional multilateral security institutions such as ARF has been widely recognized as a significant contributing element, not only to encouraging the development of multilateralism and the pursuit of common 
security, but also to bringing about and spreading these traits and norms to other areas, including Northeast Asia (Acharya 2000). However, China's government also takes a 'realistic' position towards the transition and transformation of multilateral institutions. For instance, China does not support a quick shift of ARF from confidence-building to 'preventive diplomacy' largely because she recognizes the diversity of member states' identity as well as the time-consuming and complex process of solidifying the norms of confidence building and a dialogue-oriented resolution of conflicts. Meanwhile, it is worth noting that China's involvement in multilateral institutions has promoted China's confidence and further interest in deeper and broader participation, and improved the quality of her cooperation (Johnston and Evans 1999).

The US position and attitude towards regional multilateral institutions is another determinant of the development of multilateralism. Up to now, the US government has been quite ambivalent and reserved about it. On the one hand, the United States has, in principle, offered explicit support to the construction of multilateralism and the idea of a security community (Blair 2000). On the other hand, however, the United States has explicitly and implicitly expressed suspicion of the regional multilateral institutions in East Asia. Some Americans see the regional multilateralism as a threat to the US bilateral alliance system. Others simply discredit the practical application of ARF as a useful body in resolving substantial security disputes in this area. The United States accords unilateral means, bilateral alliances and military approaches with the highest priority (The Asia Foundation 2001, 27-42; Kelly 2001). The Americans' suspicion of regional multilateralism and their stress on unilateralism and bilateralism has caused a lot of uncertainty among regional states and has had a negative impact on multilateralism.

Fourth, the biggest challenge for East Asian regional multilateralism continues to lie in diverse identities among regional states, especially among big powers (such as the United States and China), despite the fact that states in this region have a shared interest in a peaceful and stable security environment and increasingly benefit from growing economic integration among themselves.

The United States' status as a military and economic superpower with 'cultural exceptionalism' as well as its flamboyant optimism about its future, has made one American 'convinced that we know the way--politically and economically-and that therefore we have an obligation to lead others to a better future' (Maynes 2001, 50). Having such an identity as a 'destined leader', the majority in the United States seem quite concerned about how to maintain this supremacy. Therefore, US perceptions and interpretations of international regional security are quite different from those of other states, particularly developing ones. For instance, in the postCold War era, ideas and concepts such as 'hegemonic stability', 'unilateral security', 'absolute security', 'military security', and 'alliance security' have continued to attract both security analysts and policy-makers in Washington. These elements do not go in parallel with the emerging and constructing new concepts in 
regional security practices, such as 'cooperative security', 'mutual security', 'relative security' and 'comprehensive and non-alignment security' (Xinbo 2000).

The transition and transformation of China's identity is also a causal element in regional trust-building and collective identity construction. How do we define and identify China's national identity in international politics? Is it in transition from traditional great power state to a modern one with more emphasis on multilateralism and interdependence? Some observers hold that China is still a conventional nationalist state driven by a conviction that a strong state is the solution to China's crises and quest for power and wealth (Hu 2000). Some others are more optimistic, believing that multilateralist elements and norms have been (or are beginning to be) 'socialized' (Johnston and Ross 1999, 252). While controversial, one thing regarding China's international identity seems quite certain: China still finds itself in conflict with the dominant (western) identity in world politics, still viewed as being on the periphery, illegitimate and often anachronistic in terms of its international identity ( $\mathrm{Hu} 2000,57-9)$. This is particularly true if it is viewed from western-dominated international relations theory and ethnocentric western culture (which is also inexorable and inevitable as long as western powers continue to dominate IR discourse).

Some observers blame China's domestic political institutions, such as its lack of political liberalism. The implicit assumption is that, without the shared political culture and political institutions of the core big powers, China will continue to be an unstable, alien and unpredictable state, which may be a threat to the status quo. How and when China will develop a liberal political culture and institutions, though an interesting question, is not what we are here to address. Such liberal political norms and institutions, beautiful as they may be, cannot be imposed on China in its current political, economic and social condition. This is also the common belief shared by the majority of the regional states in East Asia (The Asia Foundation 2001, 12).

As demonstrated here, liberal democratic norms or institutions do not constitute a necessary condition for regional stability and peace. Therefore, the crux of the question is how the norm of multilateralism could be cultivated and ingrained in China's security practice. In this regard, the international normative structure and international interactions in which China's national identity is 'embedded' have been significant.

One the one hand, China's multilateralism is still very weak and fundamentally 'instrumental', and is yet to be 'socialized' (Wang 2000, 78 -9). But on the other hand, such a 'limitation of socialization' in China's multilateralism reflects the stark reality of conflicting normative systems in international politics to which China is exposed. As one analyst observed, 'Interactions with the international environment not only expose Chinese foreign policy makers to the principles of multilateralism, they also teach the Chinese other norms.' As a matter of fact, China's experience in the past century, from the two World Wars and Cold War to the post-Cold War era, mainly confronted the country with, and only confirmed, 
the central tenet of realism in Chinese thinking. It is also true that in the past decade, China's surging nationalism has largely been in reaction to external pressure (Zheng 2000, 109-12). Furthermore, the parallel strategy of balancing and engaging policy adopted by Washington has been a source of uncertainty for Chinese policy makers. By keeping these elements in China's identity equation, the so-called 'peripheral quality' of China's identity in international politics does not sufficiently vindicate the argument that China's multilateralism is simply strategic on the part of the Chinese government, as realist analysts are ready to insist. Rather, it demonstrates how significant it is in the international normative context to socialize an individual state's identity. If Wendt is correct to characterize the international normative/cultural context into different levels and categories, his insights are much more incisive when he observes the difficulty and complexity of the transformation from one old normative culture into a new one in which the individual actor's identity is embedded, transformed and reconstituted (Wendt $1999,247-312$ ).

\section{References}

Acharya, Amitav. 1998. 'Collective Identity and Conflict Management in Southeast Asia'. In Emanual Adler and Michael Barnett (eds), Security Communities. Cambridge: Cambridge University Press, pp. 198-227.

Acharya, Amitav. 2000. 'Regional Institutions and Security Order in Asia', $<$ http://www.cpdsindia.org/>.

Acharya, Amitav. 1999a. 'Realism, Institutionalism, and the Asian Economic Crisis', at $<$ http://www.fas.harvard.edu>.

Acharya, Amitav. 1999b. 'International Relations theory and Cross-Strait Relations', paper presented to the International Forum on Peace and Security in the Taiwan Strait, Taipei, Taiwan, July $26-28$.

Adler, Emanual, and Michael Barnett. 1998. 'A Framework for the Study of Security Community'. In Emanual Adler and Michael Barnett (eds), Security Communities. Cambridge: Cambridge University Press.

Alagapa, Mutiah. 1998. Asia Security Practice: Material and Ideational Influences. Stanford: Stanford University Press.

Antolik, Michael. 1994. 'The ASEAN Regional Forum: The Spirit of Constructive Engagement', Contemporary Southeast Asia. 16:2, pp. 117-36,

Asia Foundation. 2001. America's Role in Asia: American Views. The Asia Foundation.

Baker, Richard W. and Charles E. Morrison (eds). 2000. Asia Pacific Security Outlook. Tokyo: Japan Center for International Exchange.

Ball, Desmond. 1996. 'Arms and Affluence: Military Acquisitions in Asia-Pacific Region'. In Michael E. Brown Sean M. Lynn-Jones and Steven E. Miller (eds), East Asia Security. Cambridge: The MTT Press.

Berry, Nicholas. 2001. 'The Security Environment in Asia', at <http://www.cdi.org>.

Blair, Dennis C. 2000. 'Security communities are the way ahead for Asia', International Herald Tribune, April 24.

Brown, Michael E. (ed.). 1997. America's Strategic Choice. Cambridge: The MIT Press. Brown, Michael E. et al. (eds). 1996. East Asia Security. Cambridge: The MIT Press. 
Burchill, Scott, and Andrew Linklater (eds). 1995. Theories of International Relations. New York: St Martin's Press

Calleo, David P. 1999. 'The United States and the Great Powers', World Policy Journal. 16:3.

Chan, Steve (ed). 1993. Special issue, 'Democracy and War: Research and Reflections', International Interaction. 18:3.

Coicaud, Jean-Marc. 1999. 'On Legitimacy and Socialization of International Politics' (manuscript).

de Mesquita, Bruce Bueno, Robert Jackman, and Randolph Siverson (eds). 1991. special issue, 'Democracy and Foreign Policy: Community and Constraint', Journal of Conflict Resolution. 35, June.

Economy, Elizabeth, and Michael Oksenberg (eds). 1999. China Joins the World: Progress and Prospect. New York: Council on Foreign Relations Press.

Frieberg, Aaron L. 1996. 'Ripe for Rivalry: Prospect for Peace in a Multipolar Asia'. In Michael E. Brown Sean M. Lynn-Jones and Steven E. Miller (eds), East Asia Security. Cambridge: The MIT Press, pp. 3-30.

Frieberg, Aaron L. 1996. 'Ripe for Rivalry: Prospect for Peace in a Multipolar Asia'. In Michael E. Brown, Sean M. Lynn-Jones and Steven E. Miller (eds), East Asia Security. Cambridge: The MIT Press.

Gilpin, Robert. 1981. War and Change in World Politics. Cambridge: Cambridge University Press.

Henderson, Errol A. 1998. 'The Democratic Peace Through the Lens of Culture, 1820-1989', International Studies Quarterly. 42, pp. 461-84.

Hobson, John M. 2000. The State and International Relations. Cambridge: Cambridge University Press.

Hopf, Ted. 1998. 'The Promise of Constructivism in International Relational Theory', International Security. 23:1.

Hu, Weixing, et al. (eds). 2000. China's International Relations in $21^{3 t}$ Century. Lanham: University Press of America.

Huntington, Samuel P. 1999. 'The Lonely Superpower', Foreign Affairs. 78, pp. 35-49.

Johnston, Alastair I. and Paul Evans. 1999. 'China's engagement with multilateral security institutions'. In Alastair I. Johnston and Robert Ross (eds), Engaging China: the Management of an Emerging Power. London: Routledge, pp. 238-64.

Johnston, Alastair Jain, and Robert S. Ross (eds). 1999. Engaging China: the Management of an Emerging Power. London: Routledge.

Johnston, Alastair Iain. 1999. 'Reflections on China Participating in the International System', World Economy and Politics (in Chinese). 7.

Journal of Peace Research. 1992. 'Special Section: Democracy, War and Peace', 29.

Kahl, Colin H. 1998/99. 'Constructing a Separate Peace: Constructivism, Collective Liberal Identity, and Democratic Peace', Security Studies. 8.2, pp. 94-144.

Katzenstein, Peter J. (ed.). 1996. The Culture of National Security: Norms and Identity in World Politics. New York: Columbia University Press.

Kelly. James A. 2001. Testimony to East Asia and Pacific Panel, June 12 at $<$ http://www.usinfo.state.gov>.

Keohane, Robert O. 1998. 'International Institutions: Two Approaches', International Studies Quarterly. 32, pp. 379-96. 
Kimura, Massato and David Welch. 1998. 'Specifying "Interests": Japan's Claim to the Northern Territories and its Implications for International Relations Theory', International Studies Quarterly. 42:2.

Kissinger, Henry. 2001. Does America Need a Foreign Policy? Toward a Diplomacy for the 21st Century. New York: Simon and Schuster.

Krasner, Stephen D. (ed.). 1983. International Regimes. Ithaca, NY: Cornell University Press.

Kupchan, Charles A. 1999. 'Life after Pax Americana', World Policy Journal. XVL:3.

Lapid, Yosef, and Friedrich V. Kratochwil (eds). 1996. The Return of Culture and Identity in IR Theory. Boulder: Lynne Rienner.

Maoz, A., and B. Russett (1993). 'Normative and Structural Causes of Democratic Peace, 1946-1986', American Political Science Review. 87

Maynes, Charles William. 2001. 'Contending Schools', The National Interest.

Naidu, G.V.C. 2000. 'Asia Pacific Security: An Analysis of Trends'. <http://idsaindia.org/an-dec.00-9.html .

Onuf, Nicholas Greenwood. 1989. World of Our Making: Rules and Rule in Social Theory and International Relations. Columbia: University of South Carolina Press.

Rock, Stephen R. 2000. Appeasement in International Politics. Kentucky: The University Press.

Ross, Robert, et al. (eds). 1995. East Asia in Transition-Toward a New Regional Order. Armonk: M.E. Sharpe.

Roy, Denny. 1996. 'Hegemony on the Horizon? China's Threat to East Asia Security' In Michael E. Brown Sean M. Lynn-Jones and Steven E. Miller (eds), East Asia Security. Cambridge: The MrT Press.

Ruggie, John G. (ed.) 1983. Multilateralism Matters. New York: Columbia University Press.

Russett, Bruce, and Harvey Starr. 1996. World Politics: The Menu for Choice. 5th edn, New York: W.H. Freeman and Co.

Russett, Bruce. 1993. Grasping the Democratic Peace. Princeton, NJ: Princeton University Press.

Schweller, Randall. 1999. 'Managing the Rise of Great Powers: History and Theory'. In Alastair I. Johnston and Robert Ross (eds), Engaging China: the Management of an Emerging Power. London: Routledge.

Segal, Gerald. 1996. 'East Asia and the "Constrainment" of China'. In Michael E. Brown Sean M. Lynn-Jones and Steven E. Miller (eds), East Asia Security. Cambridge: The MIT Press.

Swaine, Michael D., and Ashley J. Tellis. 2000. Interpreting China's Grand Strategy: Past, Present and Future. Santa Monica: RAND.

Trood, Russel, and Ken Booth. 1999. 'Strategic Culture and Conflict Management in Asia Pacific'. In Ken Booth and Russel Trood (eds), Strategic culture in the Asia Pacific Region, New York: St. Martin's Press, pp. 339-41.

Van Evara, Stephen. 1999. The Cause of War: Power and roots of International Conflict. Ithaca: Cornell.

Waltz, Kenneth. 1979. Theory of International Politics. New York: Random House.

Wang, Fei-ling. 1997. 'Ignorance, Arrogance, and Radical Nationalism: A Review of China Can Say No, 'Journal of Contemporary China. 6:14, pp. 161-5. 
Wang, Hongying. 2000. "Multilateralism in Chinese Foreign Policy: The Limits of Socialization?. In Weixing Hu et al. (eds), China's International Relations in the 21st Century: Dynamics of Paradigm Shifts. Lanham: University Press of America.

Wendt, Alexander. 1994. 'Collective Identity Formation and the International State', American Political Science Review. 88:2.

Wendt, Alexander. 1999. Social Theory of International Politics. Cambridge: Cambridge University Press.

Whiting, Allen S. 1995. 'Chinese Nationalism and Foreign Policy after Deng,' China Quarterly.142, pp. 295-316.

Whiting, Allen. 1997. 'ASEAN Eyes China: The Security Dimension', Asia Survey. 37:4.

Xinbo, Wu. 1999. 'The Outlook for Security Relations'. In Peter Koehn and Joseph Y.S. Cheng (eds), The Outlook for US- China Relations Following the 1997-1998 Summits: Chinese and American Perspective on Security, Trade and Cultural Exchange. Hong Kong: The Chinese University Press.

Xinbo, Wu. 2000. 'US Security in Asia: Implications for China-US Relations'. Washington DC: Center for Northeast Asia Policy Studies of Brookings Institute.

Zheng, Yongnian. 2000. 'Nationalism, Globalism, and China's International Relations'. In Weixing Hu et al. (eds), China's International Relations in the 21st Century: Dynamics of Paradigm Shifts. Lanham MD: University Press of America. 